\title{
Pembatasan Masa Jabatan Presiden Sebagai Upaya Menghindari Terjadinya Abuse of Power
}

\author{
Elsan Yudhistira \\ Fakultas Hukum, Universitas Indonesia \\ ${ }^{\Omega}$ Surel Koresponden: elsanyudhistira90@Yahoo.com
}

\begin{abstract}
:
President term limitation is an effort to prevent a President who takes control of the nation for a long time because the President will make it possible to abuse power. Presidential term limitation is a crucial thing to be regulated because it will make the potential abuse of power, and the authoritarian government will grow in some countries. In every nation, we can see adopting a presidential system organize about Presidential term limitation to President's candidate. Seeing that there are several types adopted by various countries that adopt the Presidential system, then it will be studied which system is the best system to decrease the possibility of the occurrence abuse of power performed by the President. The research method uses a statue approach, a historical approach, and a conceptual approach. The results of this study indicate that of the 20 (twenty) countries that adhere to the presidential system, it shows that the most widely used method is only one reelection and no re-election because with this system it is supposed that it can easily limit the term of office of the President and also can be determine fixed government. The chance of abusing power will reduce, while the system No Immediate reelection and No limitation re-election is a country that allows it to be in control for a long time without any restrictions to run for President so that the possibility of abuse of authority will be more open.
\end{abstract}

Keywords: Term limitation, President term, Abuse of Power

\begin{abstract}
Abstrak:
Pembatasan masa jabatan presiden merupakan suatu upaya untuk mencegah adanya Presiden yang memgang kekuasaan dalam waktu yang panjang akan memiliki kecenderungan untuk menyalahgunakan kekuasaan (Abuse of Power) tersebut hal ini penting tiadur karena apabila tidak dibatas maka akan membuka kemungkinan terjadinya penyalagunaan wewenang dan timbulnya otoritarianisme pada suatu negara, dapat dilihat bahwa hampir seluruh negara yang menganui sistem pemerintahan Presidensial menggatur mengenai pembatasan masa jabatan pada calon presiden. Melihat dengan adanya beberapa tipe yang dianut berbagai negara yang menganut sistem Presidensial maka akan dikaji sistem mana yang paling baik untuk mengurangi kesempatan untuk terjadinya penyalahgunaan wewenang yang dilakukan Presiden. Metode penelitian menggunakan pendekatan perundang-undangan, pendekatan historis dan pendekatan konseptual. Hasil penelitian ini menunjukan bahwa dari 20 (dua puluh) Negara yang menganut sistem Presidensial ini menunjukan bahwa sistem yang paling banyak digunakan adalah sistem Only one re-election dan No reelection dikarenaakan dengan sistem ini dianggap dapat dengan mudah membatasi masa jabatan Presiden dan juga dapat menentukan fixed government sehingga kemungkinan untuk menyalahgunakan kewenangan dapat diminimalisir, sedangkan sistem No Immediate re-election dan No Limitation reelection merupakan negara yang memungkinkan Presidennya untuk berkuasa dengan waktu yang panjang tanpa ada Batasan untuk mencalonkan diri sebagai Presiden sehingga kemungkinan untuk terjadinya penyalahgunaan wewenang
\end{abstract}


akan lebih terbuka.

Kata Kunci: Pembatasan masa jabatan, Jabatan Presiden, Penyalahgunaan kekuasaan

Submit : 07-10-2020

Accept : $17-10-2020$

Doi: http://doi.org/10.56087/aijih.v23i2.43

\section{PENDAHULUAN}

Undang-Undang Dasar 1945 sebagai konstitusi Indonesia memuat aturan-aturan dasar yang disusun agar dijadikan pedoman atau pegangan bagi pemerintah dalam menjalankan fungsi dan tugasnya bukan berdasarkan kekuasaan belaka. Dan juga menjadi ukuran dalam hidup berbangsa dan bernegara yang sesuai dengan bukti perjuangan dan ide-ide dasar yang digariskan oleh Founding Fathers kita serta sebagai arahan kepada generasi penerus bangsa dalam memimpin Negara Indonesia. ${ }^{1}$ UndangUndang Dasar 1945 terdapat pembagian kekuasaan yaitu Legislatif, eksekutif dan yudikatif, hal itu sejalan dengan teori yang dikemukakan oleh Montesquieu yaitu teori trias politica. Dalam hal ini Strong juga menjelaskan bahwa trias politica adalah pengertian pemerintah dalam arti luas yang harus mempunyai kekuasaan perundangundangan (Legislative Power), Kekuasaan Pelaksanaan (Executive Power) dan kekuasaan peradilan (Yudicial Power) yang disebut sebagai tiga bagian pemerintah dan menjelma kedaulatan dalam bernegara. ${ }^{2}$

Negara-negara yang berdasarkan pada Demokrasi Konstitusional, Undang-undang dasar memiliki peranan sebagai pembatas kekuasaan pemerintah sedemikian rupa sehingga tidak menggunakan kekuasaan denan sewenang-wenang sehingga hak-hak rakyat terlindungi, ${ }^{3}$ Gagasan seperti ini dinamakan konstitusionalisme, dan hal ini juga yang dianut pada Pemerintahan di Indonesia yang tertuang pada Undang-Undang Dasar $1945 .{ }^{4}$

Batasan masa jabatan Presiden tecipta pada sistem Pemilihan Presiden di Amerika Serikat, George Washington selaku Presiden pertama Amerika Serikat membuat kebijakan yang tidak tertulis ketika ia menolak untuk masa jabatan ketiganya pada tahun

1 Thalib, D., \& Hamidi, J. Ni'matul Huda, (2008). Teori dan Hukum Konstitusi, Jakarta: PT RajaGrafindo Persada, Hlm. 19

2 Ibid

${ }^{3}$ Suny, I. (1977). Pergeseran Kekuasaan Eksekutif: Suatu Penyelidikan Dalam Hukum Tatanegara. Aksara Baru. Hlm, 42

4 Thalib, D., \& Hamidi, J. Ni'matul Huda, (2008). ibid, Hlm, 27 
1796, lalu Franklin D. Roosevelt lah yang menggunakan kekosongan hukum mengenai jabatan presiden di amerika serikat dan memenangi pemilihan presiden 4 kali dari tahun 1932-1944, dan sepeninggalan Franklin D. Roosevelt terciptalah Batasan 2 periode jabatan Presiden di Amerika serikat yang dikodifikasikan pada Amanademen ke 22 Konstitusi Amerika serikat pada tahun $1951^{5}$. Lalu terciptalah kesadaran pada negaranegara lain sepereti di Amerika Latin yang sukse menganut Batasan masa jabatan dalam masa kebangkitan dictator, Argentina pada tahun 1853 setelah Juan manuel de rosas, dan Mexico pada tahun 1917 setelah Porfirio Diaz. Negara-negara di Afrika juga mengadopsi Batasan masa jabatan pada awal tahun 1990 ketika timbul kekecewaan terhadap konsep "Presidents of life". ${ }^{6}$

Alasan Presiden yang memegang kekuasaan dalam waktu yang Panjang dapat dengan mudah menghadapi permasalahan yang dapat membuatnya mengangkat kaki dari jabatan, yang kedua masa jabatan yang Panjang dapat mengantarkan ke permasalahan kekuatan yang dilakukan oleh presiden, dan memiliki kecenderungan untuk menyalahgunakan kewenangan tersebut. ${ }^{7}$ Pada Disertasi Bill Gelfald ia menjelaskan bahwa apabila Presiden memgang kekuasaan dalam waktu yang lama dengan memperpanjang masa jabatan bahwa studi di beberapa negara justru menunjukan penyimpangan yang dilakukan presiden yang berdampak negatif seperti di negara pecahan Uni Soviet yang pendapatan domestik Bruto per kapita menurun ua tahun setelah masa jabatan Presiden diperpanjang, dan terjadi kemunduran aspek hak politik setelah empat tahun Presiden memperpanjang masa jabatan.8,9 Sebenarnya konstitusionalitas batasan masa jabatan presiden dan wakil presiden sebagai persyaratan pencalonan presiden dan wakil presiden sudah telebih dahulu dilakukan oleh Amerika Serikat. Sebagai negara yang pertama kali menerapkan sistem presidensiil ${ }^{10}$ dan kerap menjadi rujukan bagi negara-negara lain yang menganut sistem pemerintahan serupa,

\footnotetext{
${ }^{5}$ Kristen McKie, "Presidential Term Limit Contravention: Abolish, Extend, Fail, or Respect, Jurnal Comporative Political Studies, Vol. 52 No. 10 (2019) Hlm. 1502

${ }^{6}$ Maltz, G. (2007). The case for presidential term limits. Journal of democracy, 18(1), 128-142. Hlm. 135

${ }^{7}$ Gideon, Ibid. Hlm, 139

${ }^{8}$ Gelfeld, B. (2018). Preventing Deviations from Presidential Term Limits in Low-and MiddleIncome Democracies (Doctoral dissertation, PARDEE RAND GRADUATE SCHOOL). Hal 41.

${ }^{9}$ McKie, K. (2019). Presidential Term Limit Contravention: Abolish, Extend, Fail, or Respect?. Comparative Political Studies, 52(10), 1500-1534. Hal. 1515

10 Dewansyah, B., \& Zulfikar, M. A. Y. (2016). Reafirmasi Sistem Pemerintahan Presidensial dan Model Pertanggungjawaban Presidensial dalam Perubahan UUD 1945: Penelusuran Sebab dan Konsekuensi. Padjadjaran Journal of Law, 3(2), 285-309., Hlm. 342.
} 
Amerika Serikat juga mengatur batasan masa jabatan presiden dalam Amandement 22 sebagai persyaratan calon Presiden,11,12 Ketentuan dalam Section 1 Amandemen XXII Konstitusi Amerika Serikat merupakan ketentuan pembatasan masa jabatan Presiden Amerika Serikat, namun ketentuan ini juga berlaku sebagai syarat calon presiden (khusus bagi seseorang yang pernah menjabat sebagai presiden). ${ }^{13}$

Akan tetapi, kemudian tedapat perbedaan praktik ketatanegaraan masa jabatan presiden dan wakil presiden antara Indonesia dengan Amerika Serikat. Di Amerika Serikat, dimulai dari Presiden pertama Amerika Serikat, George Washington kemudian diikuti oleh para presiden setelahnya, mereka memberlakukan batasan dua kali masa jabatan untuk masa jabatan mereka sendiri. ${ }^{14}$ Sehingga sejak saat itulah ketentuan batasan masa jabatan Presiden Amerika serikat yaitu maksimal dua kali masa jabatan telah diikuti dan dan dianggap sebagai konvensi ketatanegaraan yang tidak tertulis dalam konstitusi, namun terus dipatuhi layaknya ketentuan tersebut diatur dalam konstitusi. ${ }^{15}$ Sedangkan di Indonesia, kekosongan hukum terkait pengaturan batasan masa jabatan presiden dan wakil presiden yang tidak diatur dalam konstitusi justru dimanfaatkan oleh Presiden Sukarno dan Presiden Seoharto untuk melanggengkan masa jabatannya sebagai Presiden Indonesia. ${ }^{16}$

Sepeninggal Franklin Delano Roosevelt, mulai muncul desakan agar konstitusi Amerika Serikat mengatur secara tegas batasan masa jabatan presiden dan menjadikan batasan masa jabatan tersebut sebagai syarat konstitusional pencalonan presiden dan wakil presiden di Amerika Serikat. Desakan tersebut berakhir ketika Amandemen ke-22 Konstitusi Amerika Serikat disahkan oleh negara bagian pada Februari pada 27 Februari 1951. Sejak saat itulah ketentuan tentang batasan masa jabatan Presiden dan Wakil Presiden Amerika Serikat ditentukan secara tegas dan ekspilisit dalam konstitusi. ${ }^{17}$ Kemudian batasan masa jabatan tersebut juga dijadikan sebagai syarat konstituional

11 Mochammad Isaeni Ramadhan, Jabatan Wakil Presiden Menurut Hukum Tata Negara Indonesia, (Sinar Grafika, Jakarta:2015) Hlm. 5.

${ }^{12}$ Huda, N. M. (2012). Hukum Tata Negara Indonesia Edisi Revisi. Jakarta: Rajawali Pers.

13 Mochammad Isaeni Ramadhan, Ibid. Hlm, 19

14 Tom Murse, "How Many Years Can a President Serve in the White House?", https://www.thoughtco.com/why-presidents-only-serve-two-terms-3367979, (Diakses pada tanggal 0204-2020 Pukul 19.10)

15 Tom Murse, Ibid

16 Syawawi, R. (2016). Pengaturan Pemberhentian Presiden dalam Masa Jabatan Menurut UUD 1945 (Studi Komparatif Sebelum dan Sesudah Perubahan). Jurnal Konstitusi, 7(6), 051-096. Hal. 71

17 Dixon, R., \& Landau, D. (2019). Constitutional End Games: Making Presidential Term Limits Stick. Hastings LJ, 71, 359. HIm. 393. 
pencalonan presiden dan wakil presiden di Amerika Serikat. Dengan demikian, ketentuan batasan masa jabatan Presiden dan Wakil Presiden Amerika Serikat tidak hanya menjadi peraturan tidak tertulis (konvensi ketatanegaraan), namun juga telah jelas konstitusionalitasnya dalam Konstitusi Amerika Serikat. ${ }^{18}$

Sejarah ketatanegaraan di Amerika Serikat tersebut sebenarnya juga dapat menjadi pelajaran bagi Indonesia yang juga sedang menghadapi permasalahan yang sama. Amerika Serikat pernah mengalami masa ketika ketentuan batasan masa jabatan dan persyaratan presiden dan wakil presiden tidak dituangkan secara eksplisit dalam konstitusi, seperti kondisi Indonesia saat ini. Akan tetapi, fakta dalam sejarah ketatanegaraan kedua negara tersebut menjadi bukti bahwa ketentuan yang rawan untuk dipolitisasi demi melanggengkan kekuasaan, apabila tidak diatur secara tegas dan eksplisit dalam konstitusi, maka akan menimbulkan celah untuk oknum politisi melanggengkan kekuasaannya secara terus-menerus. Oleh karena itu, belajar dan berefleksi dari sejarah ketatanegaraan Indonesia pada masa orde lama dan orde baru serta sejarah ketatanegaraan Amerika Serikat, sebaiknya diperlukan amandemen terhadap Pasal 7 UUD NRI 1945 untuk mencegah hal-hal negatif dari sejarah akan terulang pada masa akan datang. ${ }^{19}$

Adanya amandemen Pasal 7 Undang-undang Dasar 1945 menjelaskan bahwa masa jabatan Presiden dibatasi dengan hanya dua kali periode. Pembatasan masa jabatan presiden setelah diamandemen Pasal 7 Undang-Undang Dasar 1945 dapat menghindari kekuasaan yang Contiuinitas, bersifat otoriter dan menghindari adanya Abuse of Power. ${ }^{20}$

\section{METODE}

Jenis Penelitian ini adalah Penelitian hukum normatif, yakni menggunakan tiga pendekatan, yakni Pendekatan perundang-undangan (Statute approach), Pendekatan Historis (Historical approach), dan Pendekatan Konseptual (Conceptual approach), Teknik pengumpulan bahan hukum primer dan sekunder yang digunakan dalam penelitian ini adalah studi pustaka (library research), yaitu metode pencarian dan inventarisasi bahan hukum primer dan sekunder yang dengan cara menelusuri dokumen, buku-buku

18 Dixon, R., \& Landau, D. (2019). Ibid, Hal. 395

19 Hendra, H. (2016). Pertanggungjawaban Politik Presiden Pasca Amandemen Uud 1945. JWP (Jurnal Wacana Politik), 1(1), Hal. 33

${ }^{20}$ Hendra.H (2016). Ibid, Hal.34 
literatur, jurnal hukum, dan peraturan perundang-undangan yang terkait dengan obyek penelitian. ${ }^{21}$ Bahan-bahan hukum yang telah diperoleh akan diuraikan dan disajikan secara deskriptif dalam penulisan yang lebih sistematis. Metode interpretasi gramatikal, interpretasi sistematis, interpretasi historis, dan interpretasi telelologis, akan digunakan sebagai alat bantu dalam mengolah dan menganalisis bahan-bahan hukum yang ada. Selanjutnya hasil penelitian akan disimpulkan dengan menggunakan metode deduktif, yakni menarik kesimpulan dari suatu hal yang bersifat umum terhadap permasalahan kongkret yang dihadapi dalam penelitian ini.

\section{PEMBAHASAN}

\section{A. Masa Jabatan Presiden di Berbagai Negara yang menganut Sistem Presidensial}

\section{Amerika Serikat}

Dalam United States Constitutuion Article II Section 1 disebutkan "The executive power shall be vested in a President of the United States of America. He shall hold his office during the Term of four Years, and together with the vice President, chosen for the same term, be elected, as follows:"22 yang artinya Kekuatan eksekutif menjadi hak Presidem Amerika. Ia memegang kekuasaan selama masa jabatan 4 tahun Bersama dengan wakil presiden yang terpilih pada periode yang sama, dan bisa mencalonkan kembali satu kali lagi atau Only one re-election. Namun ada hal menarik mengenai pencalonan presiden dan wakil presiden yang dijelaskan jurnal.... Menjelaskan bahwa Presiden yang 2 periode sebelum presiden saat ini tidak dapat menjadi calon wakil presiden. ${ }^{23}$

Article II Section 2 United State Constitution mengenai Presidential Powers mengatur: "(1) The President shall be Commander in Chief of the Army and Navy of the United States, and of the militia of the several States, when called into the actual Service of the United States; he may require the Opinion, in writing, of the principal Officer in each of the Executive Departments, upon any

${ }^{21}$ Peter Mahmud Marzuki, Penelitian Hukum (Surabaya: Kencana Prenada Media Group, 2005), hal. 32.

${ }^{23}$ Coenen, D. T. (2015). Two-Time Presidents and the Vice-Presidency. BCL Rev., 56, 1287 Hal. 1341. 
Subject relating to the Duties of their respective Offices, and he shall have Power to grant Reprieves and Pardons for Offenses against the United States, except in Cases of Impeachment. (2) He shall have Power, by and with the Advice and Consent of the Senate to make Treaties, provided two thirds of the Senators present concur; and he shall nominate, and by and with the Advice and Consent of the Senate, shall appoint Ambassadors, other public Ministers and Consuls, Judges of the supreme Court, and all other Officers of the United States, whose Appointments are not herein otherwise provided for, and which shall be established by Law; but the Congress may by Law vest the Appointment of such inferior Officers, as they think proper, in the President alone, in the Courts of Law, or in the Heads of Departments. (3) The President shall have Power to fill up all Vacancies that may happen during the Recess of the Senate, by granting Commissions which shall expire at the End of their next Session".24 Berdasarlan Article II Section 2 mengenai Presidential Powers diatas menjelaskan kekuasaan Presiden Amerika serikat akan diberikan menjadi commander in chief pada Angkatan darat dan laut Amerika, memiliki kekuatan untuk memberi pendapat dan masukan pada senat untuk membuat perjanjian dan juga Presiden AS dapat mengisi kekosongan kekuatan yang mungkin terjadi pada senat.

\section{Argentina}

Dalam Constitution of The Argentine Nation pada Second Division "Executive Power" Chapter I, Section 90 menjelaskan "The presiden and Vice President shall hold their offices for the term of four years; and they may be re elected or may succed each other for only one consecutive term. If they have been reelected or they have succeeded each other, they cannot be elected for either ot these two positions but with the interval one term ${ }^{25}$ "

Berdasarkan Second Division mengenai Executive Power, Chapter I Section 90 menjelaskan bahwa Presiden dan Wakil presiden terpilih memegang jabatan selama 4 Tahun, dan dapat dipilih kembali 1 periode kemudian. Dan apabila ia terpilih kembali pada periode selanjutnya Presiden dan wakil presiden

25 Argentina, Constitution of The Argentine Nation (1853), bagian kedua, Bab 1 Pasal 90 
tidak dapat mencalonkan diri lagi pada posisi keduanya.

\section{Angola}

Pada Angola Constitution, Chapter II mengenai Office of the President of the Republic, Section 1, Article 59 menjelaskan "The President of the Republic shall serve a five-year term of office which shall end on the swearing in of the new elected President. The President of the Republic may be re-elected for two consecutive or discontinuous terms of office ${ }^{26}$."

Berdasarkan Pasal 59 menjelaskan bahwa Presiden Republik Angola menjalani masa jabatan selama 5 tahun dan dapat terpilih kembali lagi 2 periode berturut turut atau tidak berurutan. Atau dalam kata lain dapat terpilih selama 3 periode.

\section{Afrika Selatan}

Pada South Africa Constitution Chapter V tentang The President and National Executive, Section 88 "Terms of office of President" ayat (2) menjelaskan "No Person may hold office as President for more than two terms, but when a person is elected to fill a vacancy in the office of President, the period between that election and the next election of a President Is not regarded as a term. ${ }^{27 "}$

Pada Pasal 88 ayat (2) menjelaskan bahwa Presiden tidak dapat terpilih dari 2 periode masa jabatan, akan tetapi apabila seseorang ditunjuk sebagai Presiden sementara pada periode tersebut tidak dihitung sebagai suatu periode menjabat sebagai Presiden. Dan masa jabatannya adalah 5 tahun.

\section{Bolivia}

Pada Constituent Assemly of Bolivia, Section II mengenai Presidency and Vice President of The State, Article 168 menjelaskan: "The period of the mandate of the President or Vice President is five years, and they my be re-elected once for a continuous term ${ }^{28}$."

Pada Pasal 168 menjelaskan bahwa Masa jabatan dari Presiden dan juga Wakil

\footnotetext{
${ }^{26}$ Angola, Angola Constitution (1992), Bab 2 Pasal 59.

${ }^{27}$ Afrika Selatan, South Africa Constitution, Bab 5, Pasal 88 ayat (2)

${ }^{28}$ Bolivia, Contituet Assembly of Bolivia, bagian kedua, Pasal 168.
} 
Presiden adalah 5 tahun, dan dapat terpilih kembali satu kali lagi pada masa jabatan yang berurutan.

Namun pada 2009, Bolivia President Evo Morales menggubah atasan masa jabatan presiden pada pasal 168 yang membuat ia dapat melanjutkan jabatan pada periode ketiganya. ${ }^{29}$ Dan perspektif dari perbuatan ini menarik perhatian akademisi diseluruh dunia, David landau berpendapat bahwa bahwa doktrin, amandemen konstitusi negara tersebut tidak konstitusional untuk membatasi perubahan konstitusional yang berpotensi merubah negara menjadi anti demokrasi. ${ }^{30}$

\section{Belarus}

Pada Constituent Assemly of Bolivia, Section II mengenai Presidency and Vice President of The State, Article 168 menjelaskan: "The period of the mandate of the President or Vice President is five years, and they my be re-elected once for a continuous term ${ }^{31 . "}$

Pada Pasal 168 menjelaskan bahwa Masa jabatan dari Presiden dan juga Wakil Presiden adalah 5 tahun, dan dapat terpilih kembali satu kali lagi pada masa jabatan yang berurutan.

\section{Benin}

Pada Benin's Constitution (1964), Article 16 menjelaskan bahwa "The President and Vice-President of the Republic shall be elected for five years by direct universal suffrage. They shall be eligible for reelection ${ }^{32}$.

Pada pasal 16 menjelaskan bahwa masa jabatan Presiden dan Wakil Presiden Benin adalah 5 tahun dan dapat dipilih kembali pada periode selajutnya tanpa ada Batasan (No term limits).Pada jurnal Denis M. Tull menjelaskan bahwa Presiden Boni yayi saat menjabat tidak mengambil tindakan untuk membatasi masa jabatan walaupun sudah ada tekanan public, pada hasilnya sampai

${ }^{29}$ Walsh, F. M. The Honduran Constitution is Not a Suicide Pact: The Legality of Honduran President Manuel Zelaya's Removal"(2010) 38. Georgia Journal of International and Comparative Law, 38, 339. Hal. 348

${ }^{30}$ Landau, D. (2018). Presidential term limits in Latin America: A critical analysis of the migration of the unconstitutional constitutional amendment doctrine. Law \& Ethics of Human Rights, 12(2), 225-249. Hal. 225.

${ }^{31}$ Bolivia, Contituet Assembly of Bolivia, bagian kedua, Pasal 168.

32 Benin, Benin Constituion, Pasal 16 
sekarang Presiden di benin dapat dipilih pada periode selanjutnya tanpa ada Batasan periode masa jabatan. ${ }^{33}$

\section{Brazil}

Pada Brazil Constitution Chapter II tentang Executive Branch, Section 1 ( President and Vice President of the Republic) Article 82 menjelaskan bahwa "The term of office of the President of the republic is four years and he may not be re-elected for the subsequent term. ${ }^{34}$

Pada bagian 1 mengenai President dan wakil presiden, Pasal 82 menjelaskan bahwa Masa jabatan seorang presiden adalah 4 tahun dan tidak dapat dipilih kembali pada periode selanjutnya.

\section{Filiphina}

Pada Phillipines's Constitution Article VII mengenai Executive Departement, Section 4 menjelaskan: "The President and the Vice-President shall be elected by direct vote of the people for a term of six years which shall begi at noon on the thiertieth day of June next following day of the election and shall end at noon of the same date six years thereafter. The President shall not be eligible for any reelection. No person who has succeded as President and has served as such for more than four years shall be qualified for election to the same office at any time 35,

Pada penjelasan Bab 7 Pasal 4 mengenai Presiden dan Wakil Presiden di filiphina menjabat selama 6 tahun masa jabatan dan Presiden dan wakil Presiden tidak dapat mencalonkan diri lagi pada periode masa jabatan selanjutnya.

\section{Guatemala}

Pada Political Constitution of the Republic of Guatemala Article 184 menjelaskan "The presiden and vice President of the republic will be elected by the people through universal and secret suffrage and for a single term of four

33 Tull, D. M., \& Simons, C. (2017). The institutionalisation of power revisited: Presidential term limits in Africa. Africa Spectrum, 52(2), 79-102. Hal. 85

${ }^{34}$ Brazil, Brazil Constitution, BAB II, Bagian 1 Pasal 82

${ }^{35}$ Filipina, Philippines's Constitution (1987), Bab 7, Pasal 4. 
years"36, dan mengenai re-election dijelaskan pada Article 187 yang berisi "The re-election of extension of the presidential term by any means can be punished in accordance with the law. The mandate that he pretends to exercise will be null37."

Pada Pasal 84 menjelaskan bahwa Presiden dan Wakil Presiden terpilih pada 1 masa jabatan selama 4 tahun. Dan dilanjutkan pada Pasal 187 yang mempertegas tidak boleh dilakukannya pencalonan kembali presiden yang pernah terpilih, bahkan diterangkan dapat dikenakan sanksi hukum apabila melakukannya.

\section{Korea Selatan}

Pada South Korea Constitution pada Article 70, menjelaskan "The term of office of the President is five years, and the President cannot be reelected. ${ }^{38}$ " Pada Pasal 70 tersebut sudah dijelaskan secara lengkap bahwa Presiden Korea Selatan menjabat selama 5 tahun dan tidak dapat terpilih lagi pada periode selanjutnya.

\section{Madagaskar}

Pada Madagascar Constitution (1992) Title IV, Seection I (President of the Republic) Article 4 menjelaskan "The president of the Republic shall be elected by universal direct suffrage for five-year term. He may be re-elected for one additional term. ${ }^{39}$

Pada Pasal 4 menjelaskan bahwa Presiden Madagascar terpilih selama 5 tahun dalam 1 periode, dan dapat mencalonkan diri satu kali lagi pada periode selanjutnya.

\section{Malawi}

Pada Constitution of The Republic of Malawi, Section 83 ayat (1) menjelaskan bahwa "The President and The Vice-President shall hold office for five years. ${ }^{40 "}$ Dan penjelasan lanjutannya pada Pasal 83 ayat (2) "The President or Vice-

\footnotetext{
${ }^{36}$ Guatamela, Political Constitution of the Republic of Guatemala, Pasal 184

37 Guatamela, Political Constitution of the Republic of Guatemala, Pasal 187

38 Korea Selatan, South Korea Constitution, Pasal 70.

${ }^{39}$ Madagascar, Madagascar Constitution, bagian ke 1 Pasal 45

40 Malawi, Constitution of The Republic of Malawi, Pasal 83 ayat (1)
} 
President may serve a maxiumum of two consecutive terms. ${ }^{41}$ "

Pada Pasal 82 ayat (1) dijelaskan bahwa Presiden Republik Malawi menjabat selamat 5 tahun, lalu penjelasan lanjutan pada Pasal 82 ayat (2) menjelaskan bahwa Presiden dan Wakil Presiden maksimal menjabat selama 2 periode berturu-turut.

\section{Mexico}

Pada Constitution of Mexico Article 83 menjelaskan "The President shall assume the duties of office o the first of December for a term of six years."

Pada Pasal 83 tersebut dijelaskan bahwa masa jabatan Presiden Meksiko adalah 6 tahun dan tidak dimungkinkan untuk mencalonkan lagi pada periode berikutnya.

Pada Thesis Carolina Varela Martinez megenai Pembatasan masa jabatan Presiden di Amerika Latin menjelaskan bahwa sejak diberlakukannya ketentuan ini sejak 1928, model masa jabatan ini masih digunakan dengan aman sampai sekarang dengan meninggalkan belenggu kediktatoran di masa lalu, masih ada konflik namun para calon Presiden lebih memilih menunggu menghabiskan masa jabatan selama 6 tahun daripada bersaing menentang rezim yang sedang berkuasa. ${ }^{42}$

\section{Nicaragua}

Pada Nicaragua's Constitution (1987) Article 148 menjelaskan "The President and the Vice President shall exercise their functions for a period of five years counting from their assuming office on the tenth of January of the year following their election. During this period they shall enjoy immunity, in accordance with the law.43" dan pada Article 147 poin (a) menjelaskan hal-hal apa saja yang tidak memungkinkan untuk mencalonkan Presiden dan Wakil Presiden yaitu: "Persons who have exercise the full powers of presidency at any time during the period when the election for the following term is held, nor anyone who has

${ }^{41}$ Malawi, Constitution of The Republic of Malawi, Pasal 83 ayat (2)

42 Varela Martínez, C. (2016). Presidential Term Limits: Political and economic effects of reelection in Latin America (1990-2010) (Doctoral dissertation, University of Essex).

Hal. 64

43 Nikaragua, Nicaragua's Constitution (1987), Pasal 148 
exercised them for two presidential terms. ${ }^{4 "}$

Pada Pasal 148 menjelaskan bahwa masa jabatan Presiden Nikaragua adalah 5 tahun, lalu dijelaskan kembali pada pasal 147 poin (a) mengenai Orang yang telah menggunakan kekuasaan kepresidenan ketika pemilihan untuk masa jabatan berikutnya dilaksanakan, atau siapapun yang menggunakan kekuasaan tersebut untuk 2 periode kepresidenan. Akan tetapi saat ini di Nikaragua, National Assembly telah menghapus Batasan masa jabatan, maka dari itu Presiden Nikaragua sekarang Daniel Ortega telah menjabat pada periode ketiganya semenjak terpilih tahun 2007. (No limitation re-election)

\section{Peru}

Pada Political Constitution of Peru pada Article 112 menjelaskan "The Presidential term of office lasts five years. There is no immediate reelection. A former President may run again following at least on constitutional term, subject to the same conditions. ${ }^{45 "}$

Pada penjelasan Pasal 112 menjelaskan bahwa Presiden di Peru memiliki masa jabatan selama 5 tahun. Namun tidak dapat mencalonkan diri secara berurutan, akan tetapi bisa mencalonkan kembali setelah masa jabatan Presiden selanjutnya telah selesai.

\section{Republik Kongo}

Pada Congo Constitution Title IV Article 68 (Election, Term, Eligiility) ayat (1) menjelaskan bahwa "The President of the Republiic shal be elected for five years by direct universal suffrage. He shall be re-eligible one single time.46"

Pada Pasal 68 ayat (1) memiliki penjelasan bahwa Presiden Republik Kongo menjabat selama 5 tahun dan dapat terpilih kembali pada satu periode selanjutnya.

\section{Turki}

Pada The Constitution of the Republic of Turkey (1980) Chapter two: Executive pada Article 101 menjelaskan "The President of the Republic shall be elected for

44 Nikaragua, Nicaragua's Constitution (1987), Pasal 147 poin (a)

45 Peru, Political Constitution of Peru (1993), Pasal 112.

46 Republik Kongo, Congo Constitution, Bab 4, Pasal 68 ayat (1) 
a term of office of seven years by the Turkish Grand National Assembly from among its own members who are over 40 years of age and who have completed their higher education or from among Turkish citizens who fulfill these requirements and are eligible to be deputies ${ }^{47}$." Dan penjelasan lanjutanya bahwa "The President of the Republic cannot be elected for a second time. ${ }^{48 \text { " }}$

Pada penjelasan Pasal 101 menjelaskan bahwa Masa jabatan Presiden Turki adalah 7 tahun, dan memiliki penjelasan lanjutan yang menegaskan bahwa tidak memungkinkan untuk mencalonkan lagi pada periode selanjutnya.

\section{Venezuela}

Pada Constitution of the Republic of Venezuela, Title VI "The National, Executive Power" Article 185 menjelaskan "Anyone who has occupied the Presidency of the Republic for a constitutional term or for more than half thereof may not again be President of the Republic or perform that office within the ten years following the termination of his mandate ${ }^{49}$."

Pada Pasal tersebut menjelaskan bahwa tidak boleh seorang presiden melanjutkan Periode jabatannya secara berurutan, akan tetapi setelah 10 tahun semenjak jabatannya selesai ia dapat mencalonkan diri kembali sebagai Presiden, dan masa jabatan Presiden di Venezuela adalah 6 tahun. (No successive terms permitted, but multiple non successive terms permitted)

\section{Zambia}

Pada Constitution of Zambia (1991), Part IV “The Executive”, Article 35 (Tenure of Office of President) ayat (1) menjelaskan "Subject to clause and every President shall hold office for a periode of five years ${ }^{50 . " ~ D a n ~ p e n j e l a s a n ~ l a n j u t a n ~}$ pada ayat (2) "After two commencement of this Connstitution no person who holds or has held office as Presiden for two terms of five years each, shall be eligible for re-election to that office ${ }^{51}$."

Pada penjelasan Pasal 35 ayat (1) dan (2) adalah Presiden Zambia memiliki

\footnotetext{
47 Turki, The Constitution of the Republic of Turkey, Pasal 101.

48 Ibid

49 Venezuela, Constitution of The Republic of Venezuela, Pasal 185

50 Zambia, Constitution of Zambia, Bab 4, Pasal 35 ayat (1)

51 Zambia, Constitution of Zambia, Bab 4, Pasal 35 ayat (2)
} 
masa jabatan selama 5 tahun dan dapat mencalonkan diri kembali pada periode selanjutnya.

\section{B. Konsep dan manfaat Masa Jabatan}

Terdapat 4 (Empat) Konsep masa jabatan sesuai dari hasil penelitian NegaraNegara yang menganut system Presidensial, yaitu No re-election, No Immediate re-election, Only one re-election, dan No Limitiation re-election yang memiliki penjelasan sebagai berikut:

a) No re-election: Tidak ada kemungkinan untuk mencalonkan diri lagi sebagai Presiden setelah masa jabatan pertamanya selesai. Contoh Negara yang menggunakan sistem ini yaitu Afrika Selatan, Brazil, Filiphina, Guatemala, Korea Selatan, Mexico dan Turki.

b) No Immediate re-election: Tidak diperkenankan seorang Presiden untuk mencalonkan diri kembali ketika ia masih memegang jabatan, akan tetapi seorang mantan Presiden bisa mencalonkan diri kembali setidak-tidaknya setelah satu periode Presiden penggantinya menjabat sebagai Presiden. Contoh Negara yang menggunakan sistem ini yaitu Peru dan Venezuela.

c) Only one re-election: Seorang Presiden bisa mencalonkan diri kembali satu kali lagi pada periode selanjutnya, sistem ini yang paling banyak digunakan Negara dengan sistem Pemerintahan Presidensial yaitu Amerika Serikat, Argentina, Bolivia, Belarusia, Madagascar, Malawi, Republik Kongo, Zambia dan Indonesia tentu saja.

d) No Limitation re-election: Seorang Presiden bisa mencalonkan diri lagi menjadi Presiden tanpa ada batasan periode Negara yang menggunakan konsep ini adalah Benin dan Nikaragua.

Selain keempat konsep ini ternyata ada konsep lain yang digunakan Negara dengan system pemerintahan Presidensial, yaitu konsep:

e) Only two re-election: Seorang Presiden bisa mencalonkan diri kembali sebanyak 2 (dua) periode setelah ia menjabat. Negara yang menggunakan konsep ini adalah angola.

Mengenai manfaat pergantian masa jabatan dan permasalahan yang akan 
timbul apabila memegang kekuasaan dalam waktu yang Panjang menciptakan konsep masa jabatan. Batasan masa jabatan presiden memiliki beberapa manfaat lagi yaitu untuk mendorong pergantian bukan hanya semata atas keinginan individual, akan tetapi Partai politik. Batasan masa jabatan presiden memerlukan jalan keluar yang berkala bagi presiden Incumbent, dan dengan wajar bahwa suksesor dari partai politik presiden harus menghadapi oposisi. Pembatasan masa jabatan Presiden dapat mengurangi keuntungan dari Incumbent dan secara substansial dapat meningkatkan kesempatan partai politik dalam pergantian kekuasaan. ${ }^{52}$

Namun Jerremy Paul pernah berpendapat bahwa apabila seorang presiden terpilih untuk periode selanjutnya bahwa keefektifitasn presiden dalam periode lanjutannya seperti "bebek lumpuh", dikareakan sejak tahun $1951 \mathrm{di}$ Amerika Serikat ketika amandemen mengenai periode kedua presiden disahkan ada beberapa contoh pemimpin negara yang pada periode keduanya bekerja dengan sangat buruk ${ }^{53}$ dan pendapat dari Jerremy Paulpun di respon oleh Jack M. Beermann pada jurnalnya, ia berpendapat bahwa pemikiran skeptis terhadap pembatasan masa jabatan dapat melemahkan Presiden, dalam hal ini Presiden dapat mengontrol "Executive branch" untuk melanjutkan jabatannya ke periode kedua dan menguatkan kekuatan kongres dan pengadilan federal. Bahkan ketakutan terbesar untuk kemungkinan masa jabatan presiden yang tidak terbatas. Ia berpendapat untuk mencegah hal tersebut terjadi harus melibatkan Batasan masa jabatan pula pada anggota kongres dan reformasi pemisahan doktrin dan ketentuan konstitusional yang bertujuan untuk melemahkan kongres, dibandingkan meningkatkan kekuasaan Presiden secara langsung. ${ }^{54}$

Konsep jabatan 6 tahun tanpa ada kemungkinan untuk mencalonkan diri kembali,konsep ini dianggap bahwa terlalu memiliki ktergantungan yang tinggi pada para pemilih yang pertanggungjawabannya tidak jelas, dan menyebabkan menurunannya kredibilitas presiden dan menghamat bekerja

52 Zambia, Ibid

53 Paul, J. (2010). If It Quacks like a Lame Duck, Can It Lead the Free World: The Case for Relaxing Presidential Term Limits. Conn. L. Rev., 43, 1097. Hal. 1100

54 Beermann, J. M. (2010). A Skeptical View of a Skeptical View of Presidential Term Limits. Conn. L. Rev., 43, 1105. Hal.1108 
pada tujuan pemerintahan yang baik. Senator Mansfield seorang yang mendukung konsep jabatan 6 tahun tanpa ada kemungkinan untuk mencalonkan diri kembali berpendapat pada senat bahwa jika orang amaerika ingin presiden untuk focus pada kesehatan dan kesejahteraan jangka Panjang negara, maka Presiden tidak diperkenankan untuk menghabiskan waktu dan tenaga untuk tugas kampanye politik. ${ }^{55}$

Staus Washington selaku pembuat konsep masa jabatan 2 (dua) periode adlah factor ia menolak untuk melanjutkan masa jabatan periodek ketiga walaupun masih memungkinkan pada konstitusinya, dan ia menanamkan tradisi untuk presiden-presiden selanjutnya untuk membatasi masa jabatan mereka walaupun tanpa peraturan tertulis, dikarenakan ia berpendapat bahwa apabila seorang pemimpin negara tidak membatasi masa jabatannya maka ia akan mempimpin negara dengan menyalahgunakan kekuatan eksekutifnya dan mengancam kebebasan individu, ia menjadikan dirinya contoh untuk pensiun di akhir masa periode kedua untuk para suksesornya. ${ }^{56}$

Di Benua Afrika seluruh 37 Negara di dominasi oleh masa jabatan 5 (lima) tahun, dan sisanya 4 (empat),6 (enam) atau 7 (tujuh) tahun, dan rata-rata hanya dapat satu kali pemilihan ulang atau hanya dapat menjabat selama 2 (dua) periode hanya republic kongo yang mengizinkan untuk periode ketiga. Akan tetapi sejak tahun 2000 sampai 2018 Beberapa negara di Benua afrika melakukan perubahan konstitusi untuk merubah ketentuan Batasan masa jabatan ada sekitar 26 (dua puluh enam) negara yang melakukan referendum sejak tahun 2000, dengan tujuan untuk menstabilkan ketentuan hukum, dan penyetujuan secara luas untuk menetapkan aturan dasar menjalankan kekuasaan politik dan penyelesaian sengketa. ${ }^{57}$

\section{Batasan Masa Jabatan Presiden dan Wakil Presiden di Indonesia}

Iklim politik di Indonesia baik dari sisi pemilih dan oknum politisi yang akan

${ }^{55}$ Schack, L. L. (1996). Reconsideration of the Single, Six-Year Presidential Term in Light of Contemporary Electoral Trends. JL \& Pol., 12, 749. Hal 755

56 Peabody, B. G. (2001). George Washington, presidential term limits, and the problem of reluctant political leadership. Presidential Studies Quarterly, 31(3), 439-453. Hal. 442

${ }^{57}$ Wiebusch, M., \& Murray, C. (2019). Presidential term limits and the African Union. Journal of African Law, 63(S1), 131-160, Hal. 136 
dipilih, keduanya memiliki preferensi untuk melanggengkan kekuasaan bagi orang-orang yang telah dianggap berpengalaman dan profilnya dikenal luas oleh publik. ${ }^{58}$ Oleh karena itu, di Indonesia sering kali terdapat wacana untuk kembali mengusug calon-calon yang sebenarnya sudah pernah menjabat, seperti wacana untuk mengusung kembali Jusuf Kalla sebagai calon wakil presiden pada tahun 2019 atau wacana untuk mengusung Soesilo Bambang Yudhoyono sebagai calon Presiden 31 pada tahun 201959. Menurut pendapat Airlangga Pribadi (Pengajar Departemen Politik FISIP Universitas Airlangga), wacana-wacana tersebut bertentangan dengan semangat konstitusi untuk membatasi kekuasaan dan rotasi pada elite politik yang memimpin negara dan akan berdampak buruk dalam proses regenerasi politik di Indonesia karena politisi-politisi muda dan berbakat akan sulit muncul di masyarakat karena masih banyaknya politisi senior yang tetap berkeinginan untuk mencalonkan diri dalam pencalonan presiden dan wakil presiden. ${ }^{60}$

Pembatasan masa jabatan presiden adalah upaya untuk mencegah terjadinya penguasaan jabatan kekuasaan secara terus menerus yang diyakini akan menjadi dasar terjadinya penyalahgunaan kekuasaan dan kewenangan, oleh karena itu pada perubahan pertama UUD 1945 merubah ketentuan Pasal 7 yang awalnya berbunyi "Presiden dan Wakil Presiden memegang jabatannya selama masa lima tahun, dan sesudahnya dapat dipilih kemali", diubah bunyi pasalnya menjadi "Presiden dan Wakil Presiden memegang jabatan selama lima tahun, dan sesudahnya dapat dipilih kembali dalam jabatan yang sama, hanya untuk satu kali masa jabatan". ${ }^{61}$ Dengan adanya perubahan tersebut, maka dari itu periode masa jabatan Presiden menjadi lebih jelas dan terbatas, yakni hanya dapat menjabat selama 2 periode berbeda. Dengan demikian seseorang menjabat sebagai Presiden sampai 6 (enam) Periode seperti zaman kepemimpinan

58 Purnomo, C. E. (2016). Pengaruh Pembatasan Kekuasaan Presiden Terhadap Praktik Ketatanegaraan Indonesia. Jurnal Konstitusi, 7(2), 159-182. Hlm. 162

59 Ihsannudin, "Jika Gugatan Perindo dikabulkan SBY bias Nyapres lagi", https://nasional.kompas.com/read/2018/07/23/16110281/jika-gugatan-perindo-dikabulkan-sby-bisanyapres-lagi (Diakses pada tanggal 02/04/2020 Pukul 19.02)

60 Ihsanuddin, Ibid

${ }^{61}$ Al Atok, A. R. (2016). Penguatan Kependudukan Dan Pembatasan Kekuasaan Presiden Dalam Perubahan UUD 1945. Jurnal Ilmiah Pendidikan Pancasila dan Kewarganegaraan, 24(1). Hal. 3 
Soeharto tidak akan terulang lagi. ${ }^{62}$ Pembatasan masa jabatan Presiden setelah amandemen dapat menghindari dari kekuasaan yang bersifat otoritarianisme, tujuan utama dari amandemen tersebut adalah untuk Check and Balances dalam setiap Lembaga-lembaga pemerintah. Namun rumusan pasal tersebut masih memiliki celah untuk ditafsirkan dalam arti lain, seperti Batasan masa jabatan presiden dan wakil presiden tidak diberlakukan secara berturut-turut maupun tidak berturut-turut, poin pentingnya adalah orang tersebut sudah menjabat dua kali masa jabatan dalam seumur hidupnya dan tidak dapat lagi menempati jabatan yang sama.63

\section{KESIMPULAN DAN SARAN}

Pembatasan masa jabatan Presiden adalah hal yang penting karena apabila tidak dibatasi akan membuka kemungkinan terjadinya penyalahgunaan wewenang dan timbulnya otoritarinisme pada suatu negara, dapat dilihat dari keseluruhan Negara yang menggunakan sistem Pemerintahan Presidensial hampir seluruhnya menggunakan pembatasan masa jabatan pada calon Presiden tiap negara. Terdapat beberapa konsep terkait pembatasan masa jabatan yaitu No re-election, Only one re-election, No Immediate re-election dan No limitation re-election dan sistem yang paling banyak digunakan adalah sistem Only one re-election dan No re-election dikarenakan sistem ini dapat dengan mudah membatasi masa jabatan Presiden dan juga dapat menentukan Fixed Government sehingga kemungkinan untuk Abuse of Power diperkecil, sedangkan No immediate reelection dan No Limitation re-election masih digunakan oleh beberapa Negara yang menggunakan sistem pemerintahan Presidensial akan tetapi sistem ini memungkinkan Presidennya untuk berkuasa dengan waktu yang Panjang tanpa ada batasan untuk mengikuti pencalonan diri sebagai Presiden yang menimbulkan permasalahanpermasalahan seperti yang dialami Indonesia sebelum reformasi contohnya Presiden Nikaragua yang menggunakan konsep No Limitation re-election dan Venezuela yang

62 Khaerunnailla, W. O. F., Tunggul Ansari, S. N., \& Madjid, A. (2019). Urgensi Pembatasan Masa periode Anggota Dewan Perwakilan Rakyat dalam Upaya Pencegahan Penyalahgunaan Kekuasaan. Jurnal Ilmiah Pendidikan Pancasila dan Kewarganegaraan, 4(1), 176-185. Hal 177

63 Latansa, Q. D. (2019). Konstitusionalitas Batasan Masa Jabatan Presiden dan Wakil Presiden di Indonesia. Jurist-Diction, 2(2), 595-616.. Hal 604 
menggunakan konsep No Immediate re-election, memiliki kesamaan yaitu Presidennya saat ini dicap sebagai dictator dikarenakan menjabat pada waktu yang lama bahkan kepemimpinan keduanya tidak diakui Amerika Serikat. Dalam rangka untuk menghindari terjadinya Abuse of power, menurut penulis dapat menggunakan konsep No re-election dan Only one re-election merupakan langkah yang tepat untuk memperkecil kemungkinan terjadinya penyalahgunaan wewenang, dan seharusnya Negara-negara yang tidak menggunakan konsep tersebut harus mencontoh Negara-negara lain yang dominan menggunakan konsep serupa agar dictator-diktator di dunia ini tidak memiliki kesempatan untuk menyalahgunakan kewenangannya.

\section{REFERENSI}

\section{Buku}

Huda, N. M. (2012). Hukum Tata Negara Indonesia Edisi Revisi. Jakarta: Rajawali Pers.

Suny, I. (1977). Pergeseran Kekuasaan Eksekutif: Suatu Penyelidikan Dalam Hukum Tatanegara. Aksara Baru.

Thalib, D., \& Hamidi, J. Ni'matul Huda, (2008). Teori dan Hukum Konstitusi, Jakarta: PT RajaGrafindo Persada.

\section{Jurnal Ilmiah, Skripsi, Thesis dan Disertasi}

Al Atok, A. R. (2016). Penguatan Kependudukan Dan Pembatasan Kekuasaan Presiden Dalam Perubahan UUD1945. Jurnal Ilmiah Pendidikan Pancasila dan Kewarganegaraan, 24(1).

Beermann, J. M. (2010). A Skeptical View of a Skeptical View of Presidential Term Limits. Conn. L. Rev., 43, 1105.

Coenen, D. T. (2015). Two-Time Presidents and the Vice-Presidency. BCL Rev., 56, 1287.

Dewansyah, B., \& Zulfikar, M. A. Y. (2016). Reafirmasi Sistem Pemerintahan Presidensial dan Model Pertanggungjawaban Presidensial dalam Perubahan UUD 1945: Penelusuran Sebab dan Konsekuensi. Padjadjaran Journal of Law, 3(2), 285-309. 
Dixon, R., \& Landau, D. (2019). Constitutional End Games: Making Presidential Term Limits Stick. Hastings LJ, 71, 359.

Gelfeld, B. (2018). Preventing Deviations from Presidential Term Limits in Low-and Middle-Income Democracies (Doctoral dissertation, PARDEE RAND GRADUATE SCHOOL).

Hendra, H. (2016). Pertanggungjawaban Politik Presiden Pasca Amandemen Uud 1945. JWP (Jurnal Wacana Politik), 1(1).

Khaerunnailla, W. O. F., Tunggul Ansari, S. N., \& Madjid, A. (2019). Urgensi Pembatasan Masa periode Anggota Dewan Perwakilan Rakyat dalam Upaya Pencegahan Penyalahgunaan Kekuasaan. Jurnal Ilmiah Pendidikan Pancasila dan Kewarganegaraan, 4(1), 176-185.

Landau, D. (2018). Presidential term limits in Latin America: A critical analysis of the migration of the unconstitutional constitutional amendment doctrine. Law \& Ethics of Human Rights, 12(2), 225-249.

Latansa, Q. D. (2019). Konstitusionalitas Batasan Masa Jabatan Presiden dan Wakil Presiden di Indonesia. Jurist-Diction, 2(2), 595-616.

Maltz, G. (2007). The case for presidential term limits. Journal of democracy, 18(1), 128142.

McKie, K. (2019). Presidential Term Limit Contravention: Abolish, Extend, Fail, or Respect?. Comparative Political Studies, 52(10), 1500-1534.

Paul, J. (2010). If It Quacks like a Lame Duck, Can It Lead the Free World: The Case for Relaxing Presidential Term Limits. Conn. L. Rev., 43, 1097.

Peabody, B. G. (2001). George Washington, presidential term limits, and the problem of reluctant political leadership. Presidential Studies Quarterly, 31(3), 439-453.

Purnomo, C. E. (2016). Pengaruh Pembatasan Kekuasaan Presiden Terhadap Praktik Ketatanegaraan Indonesia. Jurnal Konstitusi, 7(2), 159-182.

Schack, L. L. (1996). Reconsideration of the Single, Six-Year Presidential Term in Light of Contemporary Electoral Trends. JL \& Pol., 12, 749. 
Syawawi, R. (2016). Pengaturan Pemberhentian Presiden dalam Masa Jabatan Menurut UUD 1945 (Studi Komparatif Sebelum dan Sesudah Perubahan). Jurnal Konstitusi, 7(6), 051-096.

Tull, D. M., \& Simons, C. (2017). The institutionalisation of power revisited: Presidential term limits in Africa. Africa Spectrum, 52(2), 79-102.

Varela Martínez, C. (2016). Presidential Term Limits: Political and economic effects of reelection in Latin America (1990-2010) (Doctoral dissertation, University of Essex).

Walsh, F. M. The Honduran Constitution is Not a Suicide Pact: The Legality of Honduran President Manuel Zelaya's Removal"(2010) 38. Georgia Journal of International and Comparative Law, 38, 339.

Wiebusch, M., \& Murray, C. (2019). Presidential term limits and the African Union. Journal of African Law, 63(S1), 131-160.

\section{Perundang-Undangan Nasional dan Internasional}

Republik Indonesia, Undang-Undang Dasar 1945

Amerika Serikat, United State Constitution (1789).

Argentina, Constitution of The Argentine Nation (1853).

Angola, Angola Constitution (1992).

Afrika Selatan, South Africa Constitution (1996).

Bolivia, Contituet Assembly of Bolivia (2006).

Belarusia, Belarus Constitution (1994)

Benin, Benin Constituion.(1990)

Brazil, Brazil Constitution(1998)

Filipina, Philippines's Constitution (1987).

Guatamela, Political Constitution of the Republic of Guatemala (1985).

Korea Selatan, South Korea Constitution (1948).

Madagascar, Madagascar Constitution (2010).

Malawi, Constitution of The Republic of Malawi.

Nikaragua, Nicaragua's Constitution (1987).

Peru, Political Constitution of Peru (1993). 
Republik Kongo, Congo Constitution. (1996)

Turki, The Constitution of the Republic of Turkey (1982).

Venezuela, Constitution of The Republic of Venezuela (1999).

Zambia, Constitution of Zambia (1996)

\section{Media Online}

Ihsannudin, "Jika Gugatan Perindo dikabulkan SBY bias Nyapres lagi", https://nasional.kompas.com/read/2018/07/23/16110281/jika-

gugatan- perindo-dikabulkan-sby-bisa-nyapres-lagi (Diakses pada tanggal 02/04/2020 Pukul 19.02)

Tom Murse, "How Many Years Can a President Serve in the White House?", https://www.thoughtco.com/why-presidents-only-serve-two-terms3367979, (Diakses pada tanggal 02-04-2020 Pukul 19.10) 